\title{
İş Stres Düzeyinin Çalışanlarda Beslenme Durumu, Diyet Kalitesi ve Antropometrik Ölçümlere Etkisinin Değerlendirilmesi
}

\author{
Evaluation of the Effect of Job Stress Level on Employment Conditions, Diet Quality and \\ Anthropometric Measurements
}

\author{
Çiğdem Özcan ${ }^{1}$, Mevlüde Kızıl $^{2}$
}

Geliş tarihi/Received: 24.06 .2020 • Kabul tarihi/Accepted: 13.12.2020

\section{ÖZET}

Amaç: İş yaşamında stresin artması ile çalışanlarda depresyon ve kaygı gibi psikolojik; obezite ve kalp hastalıkları gibi fizyolojik zararlar oluşabilmektedir. Stresin, diyetteki sağlıksız seçimlerle ve iştah üzerindeki etkileriyle sağllk sorunlarına yol açabileceği ileri sürülmektedir. Bu çalışmada, iş stresi ve geriliminin beslenme durumu ve antropometrik ölçümler üzerine etkisinin değerlendirilmesi amaçlanmıştır.

Bireyler ve Yöntem: Araştırma, bir devlet üniversitesinde idari personel, temizlik personeli ve aşçı olarak çalışan 20-65 yaş arası 34 kadın ve 150 erkek ile yürütülmüştür. Bireylerin beslenme alışkanlıklarını, iş stres durumlarını belirlemek amacıyla anket formu uygulanmıştır. Bireylerin 24 saatlik besin tüketim kayıtları ile Sağlıklı Yeme İndeksi (SYİ) puanları hesaplanmış; antropometrik ölçümleri alınmıştır.

Bulgular: İş gerilimi olmayan ve SYI puanı kötü düzeyde olanların oranı idari personelde daha düşük bulunmuştur. İş gerilimi olmadığı durumda da aş̧̧ların \%76.9’unun, temizlik personelinin \%89.5’unun ve idari personelin \%67.9’unun bel kalça oranlarının yüksek olduğu ve bu durumun obezite ile ilişkili hastalıklar açısından risk oluşturabileceği belirlenmiştir. İş gerilim durumuna göre temizlik personelinin yağ, posa, $\mathrm{B}_{1}, \mathrm{~B}_{2}, \mathrm{C}$ vitamini, niasin, magnezyum ve demir alımları anlamlı bir fark göstermiştir $(p<0.05)$. Temizlik personelinin yağ, posa alımları iş stresi puanı ile anlamlı negatif bir ilişki göstermiştir $(\mathrm{p}<0.05)$. İdari personelde ise iş stresi puanı, meyve suyu puanı ve sodyum puanı ile pozitif, sebze puanı, proteinli besin alım puanı ile negatif korelasyon göstermiştir. İdari personelin, iş yükü puanı beden kütle indeksi, bel çevresi ile negatif bir ilişki göstermiştir $(\mathrm{p}<0.05)$.

Sonuç: İş stresi bireylerin beslenme kalitelerini ve antropometrik ölçümlerini etkileyen bir faktördür. İş yerinde sağllklı beslenme alışkanlıklarını kazandırmak ve iş stresini azaltmak için stratejilerin geliştirilmesi gereklidir.

Anahtar kelimeler: İşs stresi, iş gerilimi, beslenme, sağllkl yeme indeksi

\section{ABSTRACT}

Aim: As a result of increased stress in work life, psychological problems such as depression and anxiety; physiological damages such as obesity and heart diseases can occur in employees. It has been suggested that stress can cause health problems, with unhealthy choices in diet and overall effects on appetite. The aim of this study was to evaluate the relationship between job stress (JS) level, work strain (WS) and nutritional status and anthropometric measurements.

1. İletişim/Correspondence: Hacettepe Üniversitesi, Sağlkk Bilimleri Fakültesi, Beslenme ve Diyetetik Bölümü, Türkiye

E-posta: cigdem_ozcan@hotmail.com • ๑ https://orcid.org/0000-0001-7750-4520
2. Hacettepe Universitesi, Sağllk Bilimleri Fakültesi, Beslenme ve Diyetetik Bölümü, Ankara, Türkiye • • https://orcid.org/0000-0003-1380-3243 
Subjects and Method: This study included 34 women and 150 men aged 20-65 years working as administrative staff (AS), cleaning staff (CS) and cook at a public university. A questionnaire was applied to determine the nutritional habits and JS situations of individuals. The individuals' 24-hour food consumption recalls and Healthy Eating Index (HEI) scores were calculated; anthropometric measurements were taken.

Results: The ratio of those who have poor work strain (WS) and HEI score was lower in AS. In cases where there was no WS, it was determined that $76.9 \%$ of the cooks, $89.5 \%$ of the CS and $67.9 \%$ of the AS have high waist-hip ratios and this may cause a risk for obesity related diseases. The intake of fat, fiber, magnesium, iron, niacin, vitamins $\mathrm{B}_{1}, \mathrm{~B}_{2}$ and $\mathrm{C}$ showed a significant difference according to the WS status in CS ( $\mathrm{p}<0.05)$. CS's fat and fiber intakes showed a significant negative relationship with JS score $(\mathrm{p}<0.05)$. In AS, JS score was positively correlated with, fruit juice and sodium score, and negative correlated with vegetable and protein food intake score. The AS's workload score showed a negative relationship with body mass index and waist circumference $(\mathrm{p}<0.05)$.

Conclusion: JS is a factor affecting individuals' nutritional quality and anthropometric measurements. Strategies need to be developed to gain healthy eating habits and reduce JS.

Keywords: Job stress, work strain, nutrition, healthy eating index

\section{GİRIŞ}

Çalışma hayatı ekonomik, psikososyal ve kültürel yönüyle bireyin yaşantısında büyük yer kaplamaktadır. $\mathrm{Bu}$ nedenle iş yerinde yaşanan stres giderek önem kazanmaktadır. Son yıllarda aşırı rekabetçi iş ortamı, iş stresi kaynaklarını artırarak insanlar için risk oluşturma eğilimindedir (1). Bu gelişmeler doğrultusunda iş yeri kaynaklı stres hastalık olarak tanımlanmaya başlamıştır. İş ortamında oluşan stres hem dış etkenler hem de kişinin kendi kendine yarattığı faktörlerden meydana gelerek, çalışanın performansını düşürmektedir. $\mathrm{Bu}$ durum çalışanın fiziksel ve psikolojik sağlığını bozarak, iş kazalarına sebep olabilmektedir (2).

Stres faktörlerinin devam etmesi çalışanlarda stres reaksiyonlarının oluşmasına neden olmaktadır. Uzun süre devam eden iş stresi kronik yorgunluk, tükenmişlik sendromu, kardiyovasküler hastalıklar gibi tedavi edilmesi zor, maliyet ve zaman açısından ekonomik kayıplara neden olacak sonuçlara yol açabilmektedir $(3,4)$. İş yerinde oluşan kayıp çalışma günlerinin \%50-60'ının iş stresi kaynaklı olduğu belirtilmektedir (5). Avrupa Çalışma Koşulları (The European Working Conditions Survey, EWCS) 2005 yılı taramasında çalışanların ortalama \%20.0'sinin stres yaşadığı tespit edilmiştir (6).

Stresin, diyetteki sağlıksız seçimlerle ve iştah üzerindeki genel etkileriyle sağlık sorunlarına yol açabildiği belirtilmektedir (7). Artmış iş yeri talepleri, fazla mesai ve düşük diyet kalitesi, vücudun stresle baş edebilme kapasitesinde azalmaya neden olmaktadır (8). Stresin aşırı yeme, fiziksel aktivite azlığı ile birlikte metabolik riske katkıda bulunduğu da desteklenmektedir. Klinik öncesi çalışmalarda kronik stresin adipoz dokunun da içinde olduğu periferal mekanizmaları aktive ederek iç organlarda yağ ve şeker birikimini artırdığı bulunmuştur. Farelerde yapılan çalışmada yüksek yağlı ve şekerli diyet ile beslenip kronik strese maruz birakılanların, strese maruz birakılmayan farelere göre viseral adipozite ve metabolik sendromu daha hızlı geliştirdikleri saptanmıştır (9). Deneysel sonuçlarda tutarsızlık olmakla birlikte hayvan çalışmalarında strese cevap olarak hem hiperfajik hem de hipofajik bulgular elde edilmiştir (10). Bu araştırmada, iş stresi ve gerilimi ile diyet kalitesi, beslenme alışkanlıkları, antropometrik ölçümler arasındaki ilişkinin incelenmesi amaçlanmıştır. 


\section{BIREYLER VE YÖNTEM}

\section{Katılımcilar}

$\mathrm{Bu}$ çalışma, Ankara ilinde bir devlet üniversitesinin farklı birimlerinde görev yapan, herhangi bir kronik hastalığı bulunmayan, antilipidemik, antidiyabetik ilaç kullanmayan 20-65 yaş arası 34 kadın ve 130 erkek çalışan üzerinde yürütülmüştür. Çalışanlar yaptıkları görevlere göre genel idare hizmetleri $(n=58)$, temizlik personeli ( $n=62)$ ve aşçı $(n=64)$ olarak gruplandırılarak incelenmiştir. $\mathrm{Bu}$ çalışma protokolü için Hacettepe Üniversitesi Etik Kurulundan 25.10.2016 tarihinde GO 16/651-20 karar numarası ile onay raporu alınmıştır.

\section{Araştırmanın Genel Planı ve Verilerin Toplanması}

Çalışmaya katılmayı kabul eden bireylere çalışma konusunda bilgi verilmiş ve aydınlatılmış onam formu imzalatılmıştır. Beslenme alışkanlıkları, stres düzeyi ölçeği ve 24 saatlik hatırlatma yöntemini ile besin tüketim kayıtlarını içeren anket, araştırmaya katılan bireylere yüz yüze görüşme yöntemi kullanılarak uygulanmıştır. Bireylerin antropometrik ölçümleri olarak vücut ağırlığı, boy uzunluğu, bel çevresi, kalça çevresi uygun yöntemler kullanılarak ölçülmüştür (11). Beden kütle indeksi (BKİ) ve bel/kalça oranlarının değerlendirilmesinde Dünya Sağlık Örgütü tarafindan yapılan sınıflandırmalar kullanılmıştır (12).

İş stresinin değerlendirilmesinde farklı yöntemler kullanılmaktadır. Bu yöntemlerden en sık kullanılanı Karasek ve ark. (13) tarafından geliştirilen iş yüküiş kontrolü modelidir. Bu çalışmada, psikososyal iş stresini değerlendirmede kullanılan ve Türkçeye uyarlamasının geçerlilik ve güvenilirlik değerlendirmesi Demiral ve ark. (14) tarafindan yapılmış olan iş stresi ölçeği uygulanmıştır. İş stresi puanı iş yükünün iş kontrolüne oranı olarak hesaplanmıştır (14). Her bireyden alınan puanlar toplanmış, iş yükü ve kontrol ortanca değerleri hesaplanmıştır. İş yükü ve iş kontrol puanlarının ortanca değeri belirlenerek, iş yükü ortanca değerinin üstünde ve iş kontrol ortanca değerinin altında puan alanlar iş gerilimi yüksek olan bireyler olarak belirtilmiştir (15).

Bireylerin besin tüketim durumlarını ve günlük besin grupları alım miktarlarını belirlemek amacıyla 24 saatlik geriye dönük hatırlatma yöntemi kullanılmıştır (11). Bireylerin tükettikleri yemeklerin birer porsiyonlarına giren besinlerin miktarları, katılımcılara ayrıntılı olarak sorulmuş ve elde edilen veriler "Bilgisayar Destekli Beslenme Programı, Beslenme Bilgi Sistemi (BEBİS) versiyon 7'e girilerek bireylerin gün boyunca aldığı besin ögesi miktarları hesaplanmıştır. Bireylerden besin tüketim kaydı ile elde edilen verilerden Sağlıklı Yeme İndeksi (Healthy Eating Index, HEI-2010) (SYI) puanları hesaplanmıştır. Sağlıklı Yeme İndeksi (SYI), 9’u yeterlilik 3’ü kontrol bileşeni olmak üzere 12 bileşenden oluşmaktadır. Puan hesaplaması SYI raporunda belirtildiği gibi yapılmıştır $(16,17)$. Tüm bileşen gruplarında alınan yüksek puanlar diyetin beslenme rehberine daha uyumlu olduğunu göstermektedir $(16,17)$. Sağlıklı yeme indeksinden alınabilecek maksimum puan (100) üzerinden puanlamalar; 0-50 puan arası düşük, 51-80 puan arası orta, 81-100 puan arası yüksek kalite olacak şekilde üç kategoriye ayrılarak değerlendirilmiştir $(18,19)$.

\section{Verilerin İstatistiksel Değerlendirmesi}

Çalışma sonunda elde edilen veriler SPSS versiyon 23 istatistik yazılım programı ile değerlendirilmiştir. Değişkenlerin normal dağılıma uygunluğu Kolmogorov-Smirnov/Shapiro-Wilk testleri kullanılarak incelenmiştir. Tanımlayıcı istatistiklerin gösterilmesinde ortalama ve standart sapma değerleri kullanılmıştır. Kategorik değişkenlerde gruplar arasında farklılık bulunup bulunmadığı duruma göre iki veya çok gözlü Ki-kare ya da Fisher testi kullanılarak belirlenmiştir. Üç farklı birimde görev yapan katılımcılardan elde edilen veriler arasındaki farklar parametrik durumuna göre ANOVA veya Kruskal-Wallis testi uygulanarak değerlendirilmiştir. Normal dağılım durumuna göre verilerde ikişerli 
post-hoc karşılaştırmalar için Tukey testi veya MannWhitney U testi kullanılmış; Bonferroni düzeltmesi ile değerlendirilmeler yapılmıştır. Normal dağılım durumuna göre sürekli değişkenler arasındaki korelasyon Pearson veya Spearman korelasyon testi ile hesaplanmıştır. Tüm verilerde $\mathrm{p}$ değerinin 0.05 'in altında olduğu durumlar istatistiksel olarak anlamlı sonuçlar olarak değerlendirilmiştir (20).

\section{BULGULAR}

Çalışmaya katılan bireylerin görevlerine göre iş gerilimi, diyet kalite durumları ve antropometrik ölçümlerinin risk dağılımları Tablo 1'de verilmiştir. Çalışanlarda iş gerilimi en düşük $(p<0.05)$, sYİ puanına göre orta ve iyi kalitede beslenenlerin en yüksek oranı idari personel grubunda belirlenmiştir. Çalışanlarda BKİ riskli düzeyde olanların oranı temizlik görevlilerinde daha yüksek, bel kalça oranı riskli olanların oranı idari personelde daha düşük bulunmuştur $(\mathrm{p}<0.05)$.

Çalışmaya katılan bireylerin iş gerilimi ile (var/yok) SYI ve antropometrik ölçümleri riskli olanlarının dağılımı Tablo 2'de gösterilmiştir. İş geriliminin varlığında çalışanlar arasında SYİ puanı, BKİ ve bel çevresi ölçümlerinin risk dağılımları açısından istatistiksel olarak anlamlı bir farklılık saptanmamıştır (p>0.05). İş geriliminin olmadığı durumda aşçıların \%76.9'unun, temizlik personelinin \%89.5'unun ve idari personelin \%67.9'unun bel kalça oranlarının riskli grupta yer aldığı, gruplar arasındaki farklılığın temizlik personelinden kaynaklandığı belirlenmiştir $(\mathrm{p}=0.05)$.

İş gerilimi durumuna göre görev gruplarında besin ögeleri alım miktarları Tablo 3’te verilmiştir. Aşçılarda ve idari personelde iş gerilimi varlığı ile besin ögeleri alımları ortalamaları arasında istatistiksel olarak anlamlı bir farklılık saptanmamıştır. Temizlik personellerinde iş gerilim durumu ile yağ ve yağ asidi, posa, $\mathrm{B}_{1}, \mathrm{~B}_{2}, \mathrm{C}$ vitamini, niasin, magnezyum ve demir alımları açısından grup içinde istatistiksel olarak anlamlı bir fark olduğu belirlenmiştir $(\mathrm{p}<0.05)$.

Çalışanları iş stresi ölçek puanları ile besin ögeleri, SYI puanları ve antropometrik ölçüm değerleri arasındaki korelasyon analizleri Tablo 4’te gösterilmiştir. Temizlik personelinin yağ ve yağ asidi, posa alımları iş stresi puanı ile negatif; iş kontrolü puanı ile istatistiksel olarak anlamlı pozitif bir ilişki göstermiştir $(\mathrm{p}<0.05)$. Aşçıların iş yükü stres ölçeği puanı ile meyve suyu

Tablo 1. Bireylerin iş gerilim, SYİ puanları ve antropometrik ölçümlerine göre dağılımları

\begin{tabular}{|c|c|c|c|c|c|c|c|}
\hline \multirow{2}{*}{ Genel Özellikler (\%) } & & \multicolumn{4}{|c|}{ Görev } & \multirow[b]{2}{*}{$X^{2}$} & \multirow[b]{2}{*}{$\mathbf{p}$} \\
\hline & & $\begin{array}{c}\text { Aşçı } \\
(n=64)\end{array}$ & $\begin{array}{l}\text { Temizlik Personeli } \\
\qquad(n=62)\end{array}$ & $\begin{array}{l}\text { İdari Personel } \\
\quad(n=58)\end{array}$ & $\begin{array}{l}\text { Toplam } \\
(n=184)\end{array}$ & & \\
\hline \multirow{2}{*}{ Cinsiyet } & Kadın & $3.1^{\dagger}$ & $11.3^{\dagger}$ & $43.1^{\ddagger}$ & 18.5 & \multirow{2}{*}{35.49} & \multirow{2}{*}{0.0001} \\
\hline & Erkek & $96.9^{\dagger}$ & $88.7^{\dagger}$ & $56.9^{\ddagger}$ & 81.5 & & \\
\hline \multirow{3}{*}{ İş Gerilimi (\%) } & Yok & 81.2 & 61.3 & 96.6 & 79.3 & \multirow{3}{*}{22.95} & \multirow{3}{*}{0.0001} \\
\hline & Var & $18.8^{\dagger}$ & $38.7^{\dagger}$ & $3.4^{\ddagger}$ & 20.7 & & \\
\hline & Zaylf $(\leq 50)$ & $12.5^{\dagger}$ & $22.6^{\dagger}$ & $5.2^{\ddagger}$ & 13.6 & & \\
\hline \multirow[t]{2}{*}{ SYİ Puanları } & Orta $(51-80)$ & $87.5^{\dagger}$ & $77.4^{\dagger}$ & $93.1^{\ddagger}$ & 85.9 & \multirow[t]{2}{*}{9.46} & \multirow[t]{2}{*}{0.021} \\
\hline & İyi (>80) & $0.0^{\dagger}$ & $0.0 \dagger$ & $1.7 \ddagger$ & 0.50 & & \\
\hline \multirow{2}{*}{ BKİ $\left(\mathrm{kg} / \mathrm{m}^{2}\right)$} & $<25$ & 39.0 & 21.0 & 44.9 & 34.8 & \multirow{2}{*}{8.31} & \multirow{2}{*}{0.016} \\
\hline & $\geq 25$ & $61.0^{\dagger}$ & $79.0^{\ddagger}$ & $55.1^{\dagger}$ & 65.2 & & \\
\hline \multirow{2}{*}{$\begin{array}{l}\text { Bel Çevresi }(\mathrm{cm}) \\
(\text { Erkek>94, Kadın>80) }\end{array}$} & Risksiz & 40.6 & 27.4 & 37.9 & 35.3 & \multirow{2}{*}{2.65} & \multirow{2}{*}{0.26} \\
\hline & Riskli & 59.4 & 72.6 & 62.1 & 64.7 & & \\
\hline \multirow{2}{*}{$\begin{array}{l}\text { Bel Kalça Oranı } \\
(\text { Erkek>0.90, Kadın>0.85) }\end{array}$} & Risksiz & 18.8 & 11.3 & 31.0 & 20.1 & \multirow{2}{*}{7.38} & \multirow{2}{*}{0.025} \\
\hline & Riskli & $81.2^{\dagger}$ & $88.7^{\dagger}$ & $69.0^{\ddagger}$ & 79.9 & & \\
\hline
\end{tabular}

${ }_{t, \neq}$ Aynı satırda farklı işaretler istatistiksel olarak birbirinden farklıdır $(p<0.05)$ 
Tablo 2. Bireylerin iş gerilimi sınıflamasına göre antropometrik ölçümleri ve SYİ puan dağılımları

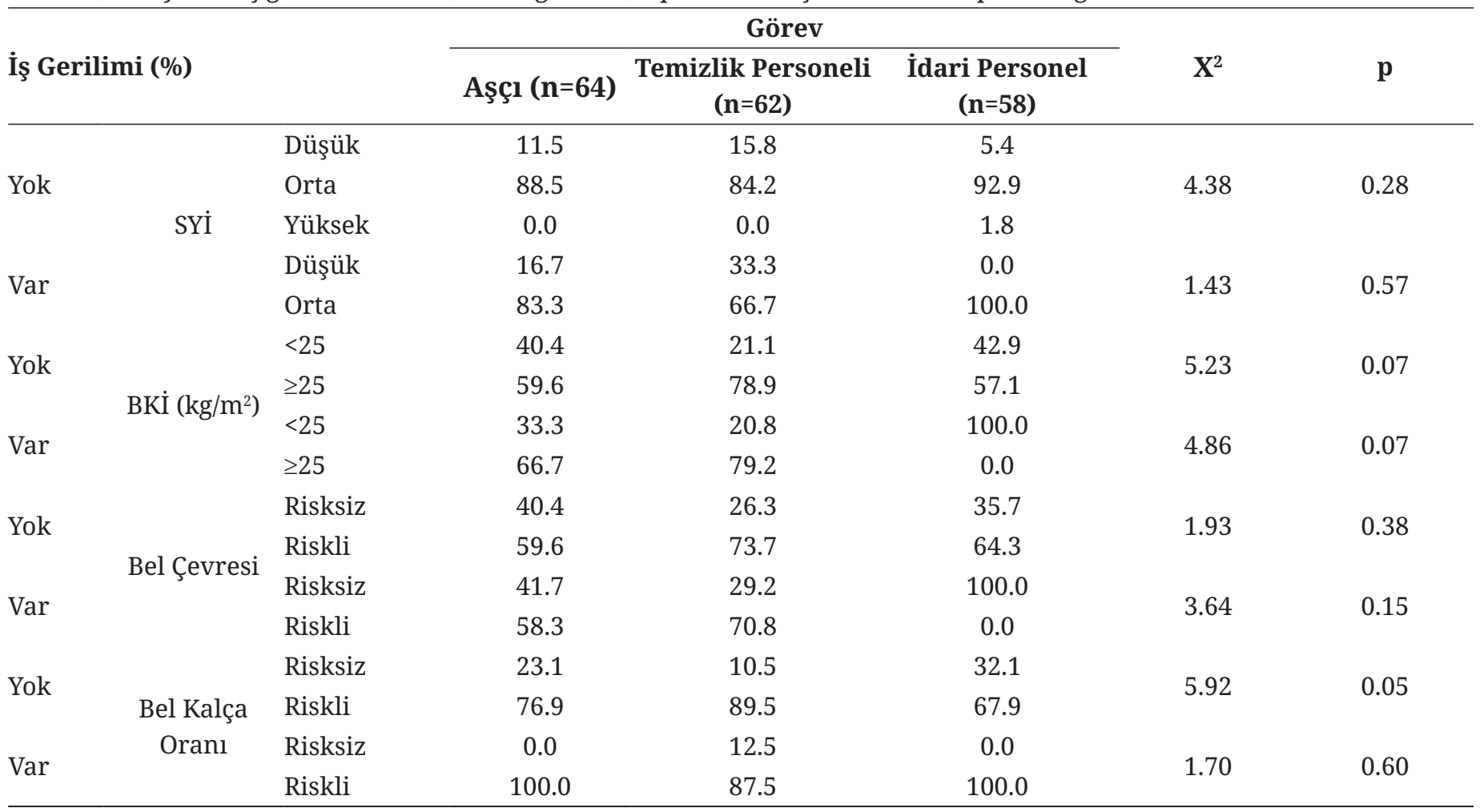

puanı arasında $(\mathrm{p}<0.01)$ pozitif; idari personellerde ise iş stresi puanı, meyve suyu $(\mathrm{p}<0.01)$ ve sodyum puanı $(\mathrm{p}<0.01)$ ile pozitif, sebze $(\mathrm{p}<0.05)$ ve proteinli besin alım puanı $(\mathrm{p}<0.05)$ ile negatif ilişkili bulunmuştur. İdari personelin, iş yükü puanı BKİ, bel çevresi ile negatif bir korelasyon göstermiştir $(\mathrm{p}<0.05)$.

\section{TARTIŞMA}

İş yaşamındaki stres, çalışanların sağlığını ve performansını olumsuz etkileyerekiş gücü kayıplarına ve sağlık harcamalarında artışa neden olmaktadır. İş yaşamında strese neden olan faktörlerin başında işin niteliği ve koşulları gelmekle birlikte yaş, cinsiyet, medeni durum, meslek ve unvan gibi değişkenlerin iş stresi üzerinde etkilerinin olabileceği belirtilmektedir (21). Smet et al. (22) tarafından yapılan çalışmada, yönetici sınıfında çalışanlarda iş gerilimi, hizmet sektöründe ve özel nitelik gerektirmeyen işlerde çalışanlardan daha düşük gözlenmiştir. Belediye çalışanı ve sağlık yöneticilerinde yapılan başka bir çalışmada, çöp toplama işini yapanlarda diğer görevleri yapanlara göre anlamlı düzeyde yüksek stres değerleri saptanmıştır (14). Toplu beslenme hizmetinde çalışanlarda iş gerilimi ve etkileyen etmenler ile ilgili yapılan çalışmada, mutfaklarda görev yapan çalışanların \%26.0'sında iş gerilimi yüksek bulunmuştur (15). Bu çalışmada da idari görevlilerin iş gerilimi daha düşük bulunmuştur. Bu veriler doğrultusunda hizmet sektörü çalışanlarının stres düzeylerinin yüksek olduğu görülmektedir. Aşçlların yaptıkları işlerin yetenek ve kontrol gerektirmesi, temizlik personelinin iş kontrollerinin düşük olması stres durumlarını artırıcı bir neden olarak gösterilebilir.

İş yerindeki stres nedenleri ile birlikte yetersiz ve dengesiz beslenme alışkanlıkları sonucunda gelişen obezite, işyerinde en sik rastlanan ve ekonomik yükü fazla olan sağlık problemlerinden biri olarak görülmektedir (23). Çalışanlarda yüksek iş taleplerine uzun süre maruz kalmanın ve düşük karar verme serbestliğinin vücut ağırlığı artışı ile ilişkili olduğu gösterilmiştir (24). Mirmahammedi et al. (25) çalışmasında; üst düzey yöneticilerin ofis çalışanlarına göre daha yüksek bel ve kalça çevresine; 


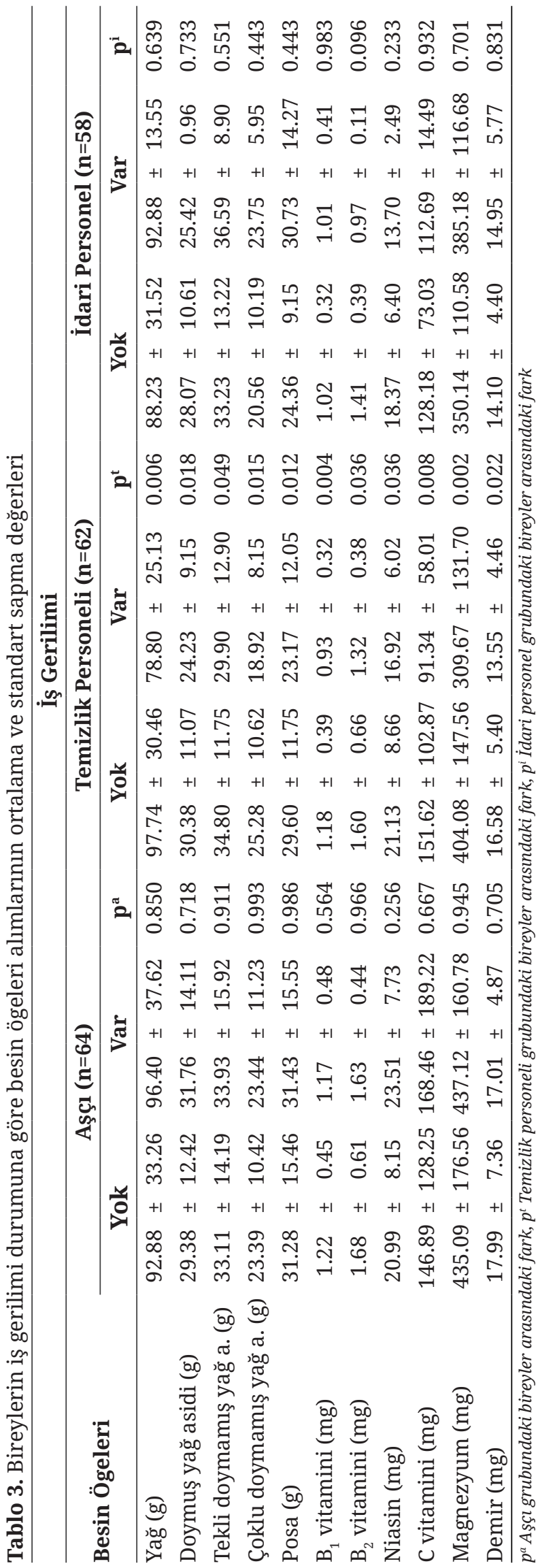

fazla iş yükü ve sorumluluk nedeniyle yüksek stres skoruna sahip oldukları belirlenmiştir. Kottwitz et al. (26) tarafından işyerindeki sosyal stresörlerde artışın ve iş kontrolündeki düşüklüğün kadınlarda BKİ oranlarında artışla ilişki olduğu bulunmuştur. Benzer olarak, Chao et al.'un (27) çalışmasında, kronik stresin, yeme isteği üzerindeki etkisi ile BKİ üzerinde değişime neden olabileceği gösterilmiştir. İşyerinin psikososyal etkilerinin fabrika çalışanlarında incelendiği araştırmada ise her iki cinsiyet için yüksek iş yükünün artmış abdominal obezite için bir risk faktörü olduğu belirtilmiştir (28). Ayrıca, yüksek ve orta gerilimli işlerde çalışan bireylerin, düşük gerilimli işlerde olanlara kıyasla daha yüksek BKİye sahip olduğu belirtilmektedir (29). Bu çalışmada, iş gerilimi olan aşçı ve temizlik personellerinin BKİ değerleri $25 \mathrm{~kg} / \mathrm{m}^{2}$ ’nin üzerinde olduğu $(\mathrm{p}>0.05)$; iş gerilimi olmayan tüm çalışanlarda da bel kalça oranı riskli olanların düzeyinin yüksek olduğu belirlenmiştir. $\mathrm{Bu}$ durum çalışanların çoğunun obezite kaynaklı sağlık riskleri taşıdığını; iş gerilimi olan aşçı ve temizlik personelinin idari personelden daha fazla risk altında olabileceğini göstermektedir. Ayrıca idari personelin, iş yükü puanı, BKİ, bel çevresi ile negatif korelasyon göstermiş olup bu durum idari personelde stresin BKİye farklı etkileri olabileceğini desteklemektedir. Çalışma sonuçları yapılan araştırmalarla tutarlılık göstermektedir ancak; gruplar arasındaki strese cevabın farklılığının bazı bulgulardaki farklı sonuçlara neden olduğu düşünülmektedir.

Farklı düzeyde stres koşulları altında günlük besin alımıyla ilgili yapılan araştırmalarda tutarsız sonuçlar bulunmaktadır. İş yerinde stres yaşayanlarda fazla besin tüketimi ile birlikte yüksek enerjili besin alımına dair bulgular elde edilmiştir (7,29-31). Stresörün kaynağına bağlı olarak orta derecede stresörün hiperfajiye, daha ciddi düzeyde stresörlerin hipofajiye neden olabileceği belirtilmektedir (9). Miki et al.'un (30) araştırmasında, depresyon semptomları gösteren Japon çalışanlarda kalsiyum, magnezyum, demir ve çinko alım düzeyleri daha düşük bulunmuştur. Bu çalışmada iş gerilimi varlığında temizlik personellerinin besin ögesi 
Tablo 4. Bireylerde is stres ölçek puanları ile besin öğeleri, SYI puanları ve antropometrik ölçümleri arasındaki korelasyon analizi sonuçları

\begin{tabular}{|c|c|c|c|c|c|c|c|c|c|}
\hline \multirow[b]{2}{*}{ Besin ve Besin Ögeleri } & \multicolumn{3}{|c|}{ Aşçı $(n=64)$} & \multicolumn{3}{|c|}{ Temizlik Personeli $(n=62)$} & \multicolumn{3}{|c|}{ İdari Personel $(n=58)$} \\
\hline & $\begin{array}{c}\text { İŞ } \\
\text { STRESİ }\end{array}$ & İş Yükü & $\begin{array}{c}\text { İş } \\
\text { Kontrolü }\end{array}$ & $\begin{array}{c}\text { İŞ } \\
\text { STRESI }\end{array}$ & İş Yükü & $\begin{array}{c}\text { İş } \\
\text { Kontrolü }\end{array}$ & $\begin{array}{c}\text { İŞ } \\
\text { STRESI }\end{array}$ & İş Yükü & $\begin{array}{c}\text { İş } \\
\text { Kontrolü }\end{array}$ \\
\hline$\overline{\text { Yağ (g) }}$ & 0.01 & -0.10 & -0.09 & $-0.314^{*}$ & -0.09 & $0.292^{*}$ & 0.03 & -0.10 & -0.14 \\
\hline Doymuş yağ asidi (g) & 0.01 & -0.12 & -0.09 & $-0.275^{*}$ & 0.00 & $0.294^{*}$ & -0.08 & -0.17 & -0.08 \\
\hline Çoklu doymamıs yağ a.(g) & 0.01 & -0.03 & -0.04 & $-0.342^{* *}$ & -0.22 & $0.263^{*}$ & 0.12 & -0.09 & -0.25 \\
\hline Posa (g) & -0.01 & -0.06 & -0.01 & $-0.349 * *$ & -0.06 & $0.349^{* *}$ & 0.05 & -0.01 & -0.09 \\
\hline Meyve suyu puanı & 0.08 & $0.253^{*}$ & 0.09 & -0.19 & 0.02 & 0.20 & $0.343^{* *}$ & 0.24 & -0.18 \\
\hline Meyve puanı & -0.17 & -0.22 & 0.02 & 0.13 & 0.14 & -0.03 & 0.09 & 0.04 & -0.11 \\
\hline Sebze puanı & -0.11 & -0.12 & 0.00 & -0.11 & $-0.388^{* *}$ & -0.06 & $-0.272^{*}$ & 0.01 & $0.375^{* *}$ \\
\hline Proteinli besin puanı & -0.11 & -0.07 & 0.05 & -0.14 & 0.10 & 0.22 & $-0.301^{*}$ & -0.13 & 0.17 \\
\hline Rafine tahillar puanı & -0.05 & -0.03 & -0.03 & -0.01 & 0.04 & 0.02 & 0.15 & 0.13 & -0.12 \\
\hline Sodyum puanı & 0.05 & 0.09 & -0.10 & -0.10 & 0.11 & 0.07 & $0.350 * *$ & 0.16 & -0.24 \\
\hline sYI toplam puanı & -0.07 & 0.02 & -0.02 & -0.12 & -0.04 & 0.12 & 0.11 & 0.11 & -0.11 \\
\hline BKİ $\left(\mathrm{kg} / \mathrm{m}^{2}\right)$ & 0.15 & 0.03 & -0.13 & -0.10 & -0.03 & 0.07 & -0.20 & $-0.266^{*}$ & -0.02 \\
\hline Bel çevresi (cm) & 0.10 & -0.06 & -0.11 & -0.09 & -0.08 & 0.08 & -0.21 & $-0.262^{*}$ & 0.01 \\
\hline
\end{tabular}

${ }^{*} p<0.05{ }^{* *} p<0.01$

alımlarının düşük olduğu belirlenmiştir. $\mathrm{Bu}$ sonuç ağır aktiviteli çalışanlarda iş geriliminin beslenme üzerindeki olumsuz etkisini desteklemektedir. Stresin yeme davranışı üzerindeki yüksek yağ alımı, düşük posa, meyve ve sebze tüketimi gibi olumsuz etkilerinin kardiyovasküler hastalıklar ve kanser oluşum risklerini arttırabileceği belirtilmektedir (33). Beslenme alışkanlıklarındaki farklılıkların iş yükü ile birlikte koroner kalp hastalıkları ile ilişkisinin incelendiği çalışmada yağ, E vitamini, kolesterol, çoklu ve tekli doymamış yağ asitleri $(\mathrm{p}<0.05)$ iş yükü ile pozitif ilişkili bulunmuştur (34). Farklı iş kolunda çalışan bireylerde iş talebi erkeklerde yüksek yağ alımı ile pozitif ilişki göstermiştir (35). İmalat işinde çalışan işçilerle yürütülen çalışmada diyet posasının, depresif belirtilerle negatif olarak ilişkili olduğu belirlenmiştir (36). Bu çalışmada iş kontrolünün yüksek olması stres azalmasında etken faktörlerden biri olup temizlik personellerde iş kontrolünün azlığı besin ögeleri alımı ile pozitif korelasyon göstermiştir. Duygusal yeme ve depresyon semptomlarının beslenme alışkanlıklarına etkisinin incelendiği bir çalışmada depresif belirtiler sebze ve meyve tüketiminin düşüklüğü ile duygusal yeme daha fazla tatlı ve enerjisi yoğun gıdalar tüketimi ile ilişkilendirilmiştir (37). Mavi yakalı çalışanlarda iş yerinde stres ve yorgunluk nedeniyle besin değeri düşük atıştırmalıkların tüketiminin fazla; meyve ve sebze alımını daha düşük olduğu belirlenmiştir (38). $\mathrm{Bu}$ çalışmamızda idari personelde iş stres puanı SYI sodyum puanı ve meyve suyu puanı ile pozitif; sebze puanı ve proteinli gıda alım puanı ile negatif ilişkili bulunmuştur. Temizlik personellerinde iş yükü sebze puanı ile negatif korelasyon göstermiştir. Bu sonuçlar iş stresi faktörlerinin çalışanları sağlıksız besin tüketimine yönelttiği söylenebilir.

Schwingshackl ve Hoffmann'ın (39) yaptığı meta analizde, yüksek kaliteli diyet ile beslenenlerde, tüm nedenlere bağlı mortalite ve kronik hastalık riskleri düşük bulunmuştur. Öner ve arkadaşları (40) kantin personelinin beslenme özelliklerini belirlemek amacıyla yaptıkları çalışmada, ortalama SYİ skorunun 59.51×1.05 olduğunu belirlemişlerdir. Bu araştırmada, iş gerilimine sahip olanların genel olarak orta kalitede beslendiği belirlenmiştir $(p>0.05)$. Stres varlığında bireylerin yüksek sodyum içerikli, yağlı ve şekerli besinleri daha fazla; sebze, meyve ürünlerini daha az tüketme eğiliminde oldukları belirlenmiştir. Bu çalışmada, stresin farklı iş kollarında farklı etkilerinin olabileceği belirlenmiştir. Çalışmanın sinırlılığı 
örneklem sayısının az; görev gruplarında ve cinsiyette dağılımının homojen olmamasıdır. Katılımcı sayısının artırılarak, daha kapsamlı çalışmalar ile bulguların desteklenmesi gerektiği düşünülmektedir.

Çalışanların kronik hastalık risklerini azaltmaları için iş yerlerinde yeterli ve dengeli beslenmelerini sağlayacak menü planlamaları yapılmalıdır. Çalışanların doğru beslenme alışkanlıklarını edinebilmesi ve sağlıklı besin seçimleri yapabilmeleri için bilinçlendirme uygulamaları yapılması gerektiği sonucuna varılmıştır.

Teşekkür: Bu makale 'İş Stres Düzeyi, Beslenme Durumu, Diyet Kalitesi ve Bazı Antropometrik Ölçümler Arasındaki İlişki’ başlıkl doktora tezine dayanmaktadır. Tez verilerinin oluşumunda katklları olan Hacettepe Üniversitesinin Sağllk, Kültür ve Spor Dairesi Başkanlığt’nın tüm birimlerindeki personele değerli katkılarından dolayı teşekkür ederiz.

Çıkar çatışması - Conflict of interest: Yazarlar çıkar çatışması olmadı̆̆ını beyan ederler. - The authors declare that they have no conflict of interest.

\section{KAYNAKLAR}

1. Keser A. İş Stresi Kaynakları. Ankara: Türk Metal Yayınlarl; 2014.

2. Oktay M. Çalışma yaşamında iş yerinde stres. Medikal açıdan stres ve çareleri, Balcıoğlu İ, editör. İ.Ü. Cerrahpaşa Tıp Fakültesi Sürekli Tıp Eğitimi Etkinlikleri, Sempozyum Dizisi No:47, 2005; s.111-116.

3. Cevizci S. İlaç sektöründe yer alan bir firmada ofis ve saha çalışanlarında stres belirtilerinin ölçülmesi, iş sağlığı ve iş veriminin araştırılması [Doktora Tezi]. İstanbul Üniversitesi Sağlık Bilimleri Enstitüsü, İstanbul; 2011.

4. Gümüştekin G, Öztemiz B. Örgütsel stres yönetimi ve uçucu personel üzerinde bir uygulama. Erciyes Üniversitesi İktisadi ve İdari Bilimler Fakültesi Dergisi. 2004;3:61-85.

5. Bacak B, Yiğit Y. İşe devamsızlığın nedenleri, ekonomik sonuçları ve azaltılması için alınması gereken önlemler. Girişimcilik ve Kalkınma Dergisi. 2010;5(1):29-44.

6. European Commission (Employment, Social Affairs and Equal Opportunities). Health and Safety at Work in Europe (1999-2007) A statistical portrait. Belgium: European Union; 2010. 97 p.

7. Wardle J, Steptoe A, Oliver G, Lipsey Z. Stress, dietary restraint and food intake. J Psychosom Res.
2000;48(2):195-202.

8. Blaug R, Kenyon A, Lekhi R. A report prepared for the work foundation's principal partners: Stress at work. London: The Work Foundation; 2007.

9. Kuo LE, Kitlinska JB, Tilan JU, Li L, Baker SB, Johnson $\mathrm{MD}$, et al. Neuropeptide $\mathrm{Y}$ acts directly in the periphery on fat tissue and mediates stress-induced obesity and metabolic syndrome. Nat Med. 2007;13:803-11.

10. Ely DR, Dapper V, Marasca J, Correa JB, Gamaro GD, Xavier $\mathrm{MH}$, et al. Effect of restraint stress on feeding behavior of rats. Physiol Behav. 1997;61:395-8.

11. Pekcan G. Beslenme durumunun saptanması. 5. Baskı. Baysal A, Aksoy M, Besler HT, Bozkurt N, Keçecioğlu S, Kutluay-Merdol T ve ark., editörler. Diyet El Kitabı. Ankara: Hatiboğlu Yayınevi; 2008. s. 67-142.

12. World Health Organization. Obesity: preventing and managing the global epidemic: report of a WHO consultation. Geneva: World Health Organization; 2000. Rapor No: 894.

13. Karasek R, Brisson C, Kawakami N, Houtman I, Bongers P, Amick B. The job content questionnaire (JCQ): An instrument for internationally comparative assessments of psychosocial job characteristics. J Occup Health Psychol. 1998;3(4):322-55.

14. Demiral Y, Ünal B, Kılıç B, Soysal A, Bilgin AC, Uçku R, et al. İş stresi ölçeğinin İzmir Konak Belediyesi'nde çalışan erkek işçilerde geçerlik ve güvenilirliğinin incelenmesi. Toplum Hekimliği Bülteni. 2007;26(1):11-8.

15. Meseri R, Öztürk \$, Demiral Y. Mutfak ve servis çalışanlarında iş gerilimi ve etkileyen etmenler. Mesleki Sağllk ve Güvenlik Dergisi. 2015;10(37):44-50.

16. Guenther PM, Casavale KO, Reedy J, Kirkpatrick SI, Hiza HA, Kuczynski KJ, et al. Update of the healthy eating index: HEI-2010. J Acad Nutr Diet. 2013;113(4):569-80.

17. Guenther PM, Kirkpatrick SI, Reedy J, Krebs-Smith SM, Buckman DW, Dodd KW, et al. The Healthy Eating Index-2010 is a valid and reliable measure of diet quality according to the 2010 Dietary Guidelines for Americans. J Nutr. 2014;22:1-9.

18. Kennedy E, Ohls J, Carlson S, Fleming K. The Healthy Eating Index: design and applications. J Am Diet Assoc. 1995;95(10):1103-8.

19. Acar TN, Yildiran H, Akbulut G, Bilici S, Koksal E, Gezmen KM, et al. Evaluation of dietary quality of adolescents using Healthy Eating Index. Nutr Res Pract. 2011;5(4):322-8.

20. Hayran M ve Hayran M. Sağlık Araştırmaları için Temel İstatistik. Ankara: Omega Araştırma; 2011.

21. Erdoğan T, Ünsar AS, Necdet ST. Stresin çalışanlar üzerindeki etkileri: bir araştırma. Süleyman Demirel Üniversitesi İktisadi ve İdari Bilimler Fakültesi Dergisi. 2009;14(2):447-61. 
22. De Smet P, Sans S, Dramaix M, Boulenguez C, De Backer G, Ferrario M, et al. Gender and regional differences in perceived job stress across Europe. Eur J Public Health. 2005;15(5):536-45.

23. Amani R, Gill T. Shiftworking, nutrition and obesity: implications for workforce health-a systematic review. Asia Pac J Clin Nutr. 2013;22(4):698-08.

24. Klingberg S, Mehlig K, Johansson I, Lindahl B, Winkvist A, Lissner L. Occupational stress is associated with major long-term weight gain in a Swedish population-based cohort. Int Arch Occup Environ Health. 2019;92(4):56976.

25. Mirmohammadi SJ, Taheri M, Mehrparvar AH, Heydari M, Kanafi AS, Mostaghaci M. Occupational stress and cardiovascular risk factors in high-ranking government officials and office workers. Iran Red Crescent Med J. 2014;16(8):e11747.

26. Kottwitz MU, Grebner S, Semmer NK, Tschan F, Elfering A. Social stress at work and change in women's body weight. Industrial Health. 2014;52(2):163-71.

27. Chao A, Grilo CM, White MA, Sinha R. Food cravings mediate the relationship between chronic stress and body mass index. J Health Psychol. 2015;20(6):721-9.

28. Ishizaki M, Nakagawa H, Morikawa Y, Honda R, Yamada $\mathrm{Y}$, Kawakami N. Influence of job strain on changes in body mass index and waist circumference-6-year longitudinal study. Scand J Work Environ Health. 2008;34(4):288-96.

29. Azagba S, Sharaf MF. The relationship between job stress and body mass index using longitudinal data from Canada. Int J Public Health. 2012;57(5):807-15.

30. Miki T, Kochi T, Eguchi M, Kuwahara K, Tsuruoka H, Kurotani K, et al. Dietary intake of minerals in relation to depressive symptoms in Japanese employees: the Furukawa Nutrition and Health Study. Nutrition. 2015;31(5):686-90.

31. Park S, Sung E. 'You gotta have something to chew on': perceptions of stress-induced eating and weight gain among office workers in South Korea. Public Health
Nutr. 2020;1-13.

32. Lin TT, Guo YL, Gordon C, Cayanan E, Chen YC, Ouyang $\mathrm{CM}$, et al. Association between sugar-sweetened beverage consumption as meal substitutes, workload, and obesity in nurses: A cross-sectional study. Int J Environ Res Public Health. 2019;16(24):4984.

33. Scott C, Johnstone AM. Stress and eating behaviour: implications for obesity. Obesity Facts. 2012;5(2):277-87.

34. Kawakami N, Tsutsumi A, Haratani T, Kobayashi F, Ishizaki M, Hayashi T, et al. Job strain, worksite support, and nutrient intake among employed Japanese men and women. J Epidemiol. 2006;16(2):79-89.

35. Hellerstedt WL, Jeffery RW. The association of job strain and health behaviours in men and women. Int J Epidemiol. 1997;26(3):575-83.

36. Miki T, Eguchi M, Kurotani K, Kochi T, Kuwahara K, Ito $\mathrm{R}$, et al. Dietary fiber intake and depressive symptoms in Japanese employees: The Furukawa Nutrition and Health Study. Nutrition. 2016;32(5):584-9.

37. Konttinen H, Männistö S, Sarlio-Lähteenkorva S, Silventoinen K, Haukkala A. Emotional eating, depressive symptoms and self-reported food consumption. A population-based study. Appetite. 2010;54(3):473-9.

38. Nagler EM, Viswanath K, Ebbeling CB, Stoddard AM, Sorensen G. Correlates of fruit and vegetable consumption among construction laborers and motor freight workers. Cancer Causes \& Control. 2013;24(4):637-47.

39. Schwingshackl L, Hoffmann G. Diet quality as assessed by the Healthy Eating Index, the Alternate Healthy Eating Index, the Dietary Approaches to Stop Hypertension score, and health outcomes: A systematic review and meta-analysis of cohort studies. J Acad Nutr Diet. 2015;115(5):780-800.

40. Öner C, Çatak B, Yıldız M, Erdoğan A, Canpolat İ, Seğmen Ö. Kantin çalışanlarının beslenme özellikleri (dietary features of canteen workers). Smyrna Tip Dergisi. 2013;1:7-11. 